\title{
The natural environment as an area of Corporate Social Responsibility
}

\section{Środowisko naturalne jako obszar społecznej odpowiedzialności biznesu}

*Anna Wolak-Tuzimek PhD., Faculty of Economic and Legal Sciences, Kazimierz Pulaski University of Technology and Humanities in Radom, Chrobrego Street 31, p. o. box 26-600 Radom, , Poland, e-mail: awt@uthrad.pl **Joanna Tarnawska, ENERGYWISE, Zagajnikowa Street 26, p. o. box 04-853 Warszawa, Poland, e-mail: tarnawska.jm@gmail.com
${ }^{* * *}$ Marek Chmiel, Institute of Environmental Protection - National Research Institute, Krucza Street 5/11d, p. o. box 00-548 Warszawa, Poland, e-mail:marek.chmiel@ios.edu.pl

Keywords: natural environment, Corporate Social Responsibility, area

Słowa kluczowe: środowisko naturalne, Społeczna Odpowiedzialność Biznesu, obszar

\begin{abstract}
Areas of Corporate Social Responsibility (CSR) have been defined in ISO 26000. Guidelines of the International Standardisation Organisation distinguish seven areas: corporate governance, human rights, labour practices, natural environment, fair operating practices, consumer issues, social commitment and development of local communities. This article presents good practices implemented by enterprises in the individual areas, in particular, actions in the area of the natural environment. Two research hypotheses are posited concerning the rate of implementing good CSR practices and the number of actions in the natural environment area. National Responsible Business Forum research and a survey of a group of enterprises in the Mazovian region, conducted by the authors in 2014-2016, served to verify the hypotheses. The results imply that the number of good practices realised in CSR areas tends to grow. In addition, actions in the area of the natural environment rank third with regard to good practices implemented.
\end{abstract}

๑) IOŚ-PIB

\section{INTRODUCTION}

Corporate Social Responsibility (CSR) denotes responsibility of an organisation for impact of its decisions and actions on society and environment [Maráková et al. 2015]. It is expressed as transparent and ethical actions that contribute to sustainable development and consideration of expectations of parties interested in activities of an organisation.

Enterprises that have implemented the concept of CSR conduct their operations in seven areas: corporate governance, human rights, labour practices, natural environment, fair operating practices, consumer issues, social commitment and development of local communities.

The CSR concept is an all-round strategy encompassing all aspects of enterprises; therefore, organisations have an opportunity to implement good practices in each area.

It is the objective of this article to present good practices implemented by enterprises in the individual areas, in particular, actions in the area of the natural environment.

\section{Streszczenie}

Obszary społecznej odpowiedzialności biznesu zostały określone w normie ISO 26000. Zgodnie z wytycznymi Międzynarodowej Organizacji Normalizacyjnej wyróżnia się 7 obszarów: ład organizacyjny, prawa człowieka, praktyki z zakresu pracy, środowisko naturalne, uczciwe praktyki operacyjne, zagadnienia konsumenckie, zaangażowanie społeczne i rozwój społeczności lokalnej. Celem artykułu jest przedstawienie dobrych praktyk wdrażanych przez przedsiębiorstwa w poszczególnych obszarach ze szczególnym uwzględnieniem działań w obszarze środowisko naturalne. W artykule postawiono dwie hipotezy badawcze dotyczące tempa wdrażania dobrych praktyk z obszarów CSR oraz ilości działań w obszarze środowiska naturalnego. W celu sprawdzenia prawdziwości postawionych hipotez wykorzystano badania ogólnopolskie prowadzone przez Forum Odpowiedzialnego Biznesu oraz badania własne przeprowadzone w latach 20142016 na grupie przedsiębiorstw województwa mazowieckiego. Z analizy wyników badań wynika, że ilość zrealizowanych dobrych praktyk w obszarach CSR wykazuje tendencję wzrostową. Ponadto działania w obszarze środowisko naturalne plasują się na trzecim miejscu pod względem wdrożonych dobrych praktyk.

The following research hypotheses are posited:

$\mathrm{H}: 1$ Enterprises increasingly often implement good practices in CSR areas. The rising numbers of these actions is evidence of enterprises' high activity in the field of social responsibility.

$\mathrm{H}: 2$ Good practices in the area of natural environment are not the largest grouping of socially responsible actions. A majority of practices are implemented in areas of social commitment, development of local communities as well as labour.

The theoretical section uses the method of critical analysis of CSR literature, whereas the statistical analysis of data from the authors' electronic mail survey and Responsible Business Forum (RBF) secondary research is applied to the empirical part. 


\section{THE NOTION AND AREAS OF CSR - LITERATURE REVIEW}

Specialist literature fails to offer unambiguous interpretations of CSR, which gives rise to a range of implications [Marrewijk 2003; McWilliams et al. 2006]. CSR is a relatively comprehensive idea as it comprises both aspects of the internal environment and links to stakeholders in a social context [Hys, Hawrysz 2013; Sen, Bhattacharya 2001]. Such a broad interpretation of CSR is reflected in varying perceptions of its nature. In both theory and economic practice, CSR is treated as a philosophy of business [Wołowiec, 2004; Amalric, Hauser, 2006], a management concept [Gołaszewska-Kaczan, 2009], a factor of competitiveness [Porter, Kramer, 2006; Ratajczak, Stawicka, 2008] and a concept of voluntary consideration of social aspects by a firm [Craig Smith, 2003; Kotler, Lee, 2005]. A single universal definition of CSR is absent, as authors emphasise diverse aspects of management. This points to a multi-dimensional nature of CSR.

The concept of CSR most often denotes conducting business clearly and transparently, in consideration of ethical principles, and with a sense of responsibility for customers, employees, investors, society, environment and so on. A review of selected definitions of CSR is shown in Table 1.

According to ISO 26000, the first international CSR standard, the essence of the idea is enterprises taking responsibility for decisions and actions for society and natural environment by means of transparent and ethical conduct that [Stawicka, Wołoszyn 2013]

- Contributes to sustainable development, including public health and welfare;

- Considers expectations of stakeholders (individuals or groups interested in decisions or actions of an organisation);

- Conforms to applicable law and is consistent with international standards of conduct;

- Is integrated into actions of an organisation and practised as part of actions undertaken within the area of its impact.

The currently prevailing definition of the European Commission assumes enterprises should have, to fulfil their obligations, a mechanism for integrating social, environmental and ethical issues, as well as those relating to human rights and consumer problems, into their activities and underlying strategy, in close cooperation with interested parties, in order to (COM [2011]681) - maximise creation of values shared by owners/ shareholders, other interested parties and the society as a whole;

- recognise, prevent and relieve possible negative consequences. The CSR areas can be addressed as parts of specific groups of interest that offer general scope for socially responsible actions or, in more detail, by indicating entities and notions within the interest of CSR [Kazojć 2014].

Griffin [2005] illustrates three areas to which firms should apply socially responsible actions (Figure 1). In his opinion, actions of an organisation in respect of environment protection should be primarily based on such operations that will reduce adverse environment impact at the stages of production, normal activities and waste disposal. The area of 'external shareholders' refers to actions of an organisation for stakeholders, that is, entities that may affect, and be affected by, the organisation. The third area
Table 1. Selected definitions of Corporate Social Responsibility.

\begin{tabular}{|c|c|}
\hline Author & Definition \\
\hline H.R. Bowen (1953) & $\begin{array}{l}\text { CSR refers to obligations of enterprises } \\
\text { to carry out policies that are desirable } \\
\text { from the perspective of goals and } \\
\text { values of our society }\end{array}$ \\
\hline M. Friedman (1970) & $\begin{array}{l}\text { A concept utilising means and } \\
\text { involvement in actions to increase } \\
\text { profit in accordance with principles of } \\
\text { free competition and without using any } \\
\text { deceit in operations }\end{array}$ \\
\hline $\begin{array}{l}\text { W. C. Frederick } \\
\text { (1986) }\end{array}$ & $\begin{array}{l}\text { CSR incorporates the notion of moral } \\
\text { correctness in actions and policies. Its } \\
\text { value is a result of moral convictions } \\
\text { and constitutes a culture of ethics }\end{array}$ \\
\hline $\begin{array}{l}\text { A. McWilliams, } \\
\text { D. Siegel (2001) }\end{array}$ & $\begin{array}{l}\text { CSR is an action represented as a } \\
\text { public good beyond interests of a firm }\end{array}$ \\
\hline C. Crouch (2006) & $\begin{array}{l}\text {... conduct of firms that voluntarily } \\
\text { consider external effect on other } \\
\text { entities. CSR can be seen as external } \\
\text { regulations affecting activities of a firm }\end{array}$ \\
\hline W. Visser (2007) & $\begin{array}{l}\text { Formal and informal ways a firm } \\
\text { contributes to improving quality of } \\
\text { management, ethics, labour, social } \\
\text { relations, and environmental conditions } \\
\text { in developing countries... }\end{array}$ \\
\hline $\begin{array}{c}\text { K. Basu, } \\
\text { G. Palazzo (2008) }\end{array}$ & $\begin{array}{c}\text {... CSR is a process whereby } \\
\text { managers in an organisation take } \\
\text { relations with stakeholders into } \\
\text { account... }\end{array}$ \\
\hline $\begin{array}{l}\text { P. Hąber, } \\
\text { P. Szewczyk } \\
(2010)\end{array}$ & $\begin{array}{l}\text { Social responsibility of enterprises } \\
\text { (CRS) is a concept according to which } \\
\text { corporate responsibility consists } \\
\text { in more than generating profits to } \\
\text { shareholders (owners). The notion } \\
\text { relates to the way business decisions } \\
\text { and actions of an enterprise influence } \\
\text { all entities that deal with it inside and } \\
\text { out of an organisation. }\end{array}$ \\
\hline B. Rok (2012) & $\begin{array}{l}\text { Responsible business is a strategic and } \\
\text { long-term approach based on social } \\
\text { dialogue and searching for solutions } \\
\text { that would be of benefit to all }\end{array}$ \\
\hline $\begin{array}{l}\text { L. Lambertini, } \\
\text { A. Palestini, } \\
\text { A. Tampieri (2016) }\end{array}$ & $\begin{array}{l}\text { CSR encompasses not only growth } \\
\text { of enterprise profits but also actions } \\
\text { for employees, business partners, } \\
\text { consumers and environment }\end{array}$ \\
\hline
\end{tabular}

Source: The authors' own compilation based on Bowen (1953), Friedman (1970) Frederick (1986) McWilliams and Siegel (2001), Crouch (2006) Visser (2007), Basu and Palazzo (2008) Hąber and Szewczyk (2010), Rok (2012) and Lambertini et al. (2016).

is 'overall social welfare'. It refers to additional activities of an enterprise to improve welfare in its environment. Griffin means charity activities and support for social or cultural organisations. Businesses have been forced to undertake CSR actions by strong environmental pressure arising, for instance, from escalating competition or changing values of both customers (pro-quality and pro-ecological behaviour) and employees (drive towards development and self-fulfilment, rising appreciation of leisure). 


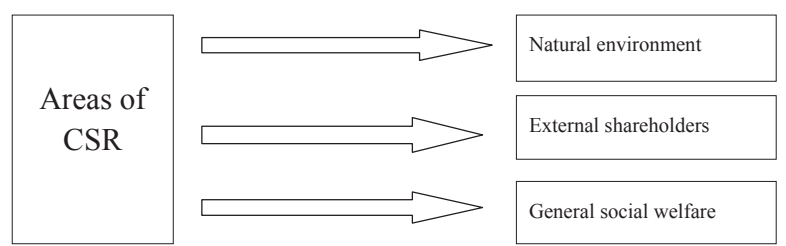

Figure 1. Areas of CSR according to Griffin.

Source: The authors' own compilation based on Griffin (2005).

CSR includes the following areas of firms' activities [Pogonowska, Wojtasiewicz 2008]:

- Market environment: suppliers, buyers, partners and competitors; CSR is expressed as application of ethical principles to contacts with the environment, use of true information and publicity, pursuit of appropriate and fair rules in processes of privatisation, mergers and takeovers;

- Public environment: public administration, public benefit institutions, social organisations, residents; CSR means firms realising projects for science, education, culture, healthcare and sports;

- Employment: management of human resources (recruitment, selection, motivation system, wages), resolution of labour conflicts, especially in supervisor-worker relations; CSR means following principles of worker subjectivity, social justice, opportunities for personal development, guarantee of stability and security, fair wages and respect for worker possessions in human resources management,

- Environment protection: technology and organisation of an enterprise's actions connected to the use of environment resources; CSR is an appropriate management of natural resources in an enterprise, obedience to environment protection regulations;

- Relations with investors: present or potential shareholders; CSR is full and reliable information for investors, keeping of promises made.

Areas of CSR are also laid down in ISO 26000. Guidelines of the International Standardisation Organisation distinguish seven areas (Figure 2).

The first area concerns corporate governance. It comprises principles and standards relating to broadly defined management. Good practices in this area should aim to boost effectiveness of organisation management whilst considering social interests, respect for stakeholders and ethical principles.

The second area is connected to human rights. Each enterprise should respect them, in particular, human dignity and civic, economic, political, social and cultural rights. In Polish circumstances, good practices in this area should arise, for example, from a need to counteract any discrimination and to reaffirm protection of worker's rights.

The third area refers to aspects of employment. In its everyday operations, an enterprise is guided by principles of working not only for its staff but also with contractors or suppliers. Good practices in this regard should not base solely on statutory regulations but should care for working conditions, health and safety, development, ongoing social dialogue and open and good relations with co-working entities [Gasiński, Piskalski 2009].
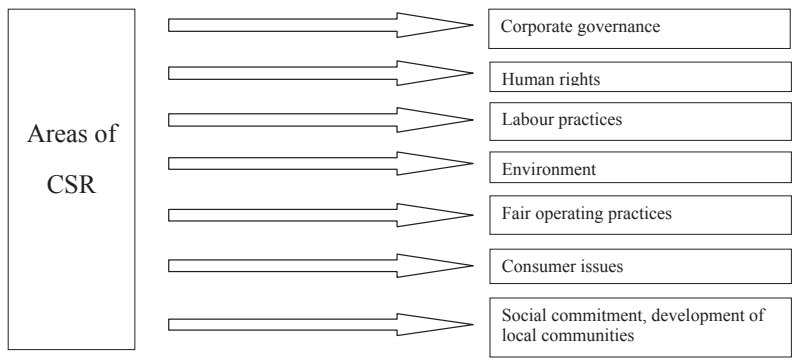

Figure 2. Areas of CSR according to ISO 26000 Source: The authors' own compilation.

Remedying of and adaptation to climate changes, protection and regeneration of the natural environment should be first of all considered as part of the fourth area, namely, protection of the natural environment.

Good practices should be designed to care for clean environment by minimising an enterprise's emissions and taking of any actions to reduce consumption of natural resources in effect of an organisation's activities.

Business ethics is the fifth area, which relates mainly to ethical relations of an enterprise with other organisations. Good practices should aim to counteract unfair competition, corruption and embezzlement; help support fair cooperation and social responsibility in the chain of supply; and respect for property rights [Sala 2015].

This sixth field concerns relations with consumers. Accordingly, each enterprise ought to be honest and transparent towards its customers. In addition, responsible marketing should be in place, product information must be accurate and true, principles of sale should be fair, consumer safety should be borne in mind, products and services safe to the public and the environment should be developed and after-sales support and complaints handling should be in place.

Market education, commitment to healthcare and consumer safety, quality of service and support and dealing with complaints are important in this area.

Issues of social commitment constitute the final area. In this connection, enterprises should actively support local communities to solve their problems. Social dialogue, involvement of social organisations in planning and realisation of social projects are some of the good practices. Actual social issues should be addressed or investments should be undertaken in areas such as education, health, culture, access to technologies or development.

\section{GOOD PRACTICES IN THE AREA OF THE ENVIRONMENT - RESULTS OF NATIONAL-SCALE RESEARCH}

RBF has prepared the report 'Responsible Business in Poland. Good Practices' every year since 2002. This is the most extensive review of socially responsible business in Poland, which contains examples of good practices and enterprises' actions.

Good CSR practices, that is, actions, programmes or projects, pursued by enterprises are grouped by the areas listed in ISO 26000: corporate governance, human rights, labour practices, natural environment, fair operating practices, consumer issues, 
Table 2. Numbers and structure of good practices in 2011-2015.

\begin{tabular}{|c|c|c|c|c|c|c|c|c|c|c|}
\hline \multirow{2}{*}{ Area } & \multicolumn{2}{|c|}{2011} & \multicolumn{2}{|c|}{2012} & \multicolumn{2}{|c|}{2013} & \multicolumn{2}{|c|}{2014} & \multicolumn{2}{|c|}{2015} \\
\hline & Number & $\%$ & Number & $\%$ & Number & $\%$ & Number & $\%$ & Number & $\%$ \\
\hline $\begin{array}{l}\text { Corporate } \\
\text { governance }\end{array}$ & 18 & 8.6 & 24 & 9.2 & 31 & 7.7 & 35 & 8.3 & 36 & 7.9 \\
\hline Human rights & 5 & 2.4 & 3 & 1.1 & 12 & 3.0 & 14 & 3.3 & 13 & 2.9 \\
\hline Labour practices & 66 & 31.6 & 60 & 22.9 & 67 & 16.6 & 84 & 20.0 & 114 & 25.1 \\
\hline $\begin{array}{c}\text { Natural } \\
\text { environment }\end{array}$ & 37 & 17.7 & 44 & 16.8 & 81 & 20.1 & 50 & 11.9 & 57 & 12.6 \\
\hline $\begin{array}{l}\text { Fair operating } \\
\text { practices }\end{array}$ & 8 & 3.8 & 16 & 6.1 & 20 & 4.9 & 29 & 7.0 & 22 & 4.8 \\
\hline Consumer issues & 4 & 1.9 & 17 & 6.5 & 22 & 5.5 & 21 & 5.0 & 26 & 5.7 \\
\hline $\begin{array}{c}\text { Social } \\
\text { commitment and } \\
\text { development of } \\
\text { local communities }\end{array}$ & 71 & 34.0 & 98 & 37.4 & 170 & 42.2 & 187 & 44.5 & 186 & 41.0 \\
\hline Total & 209 & 100 & 262 & 100 & 403 & 100 & 420 & 100 & 454 & 100 \\
\hline
\end{tabular}

Source: The authors' own compilation based on the 2011-2015 report of RBF.

social commitment and development of local communities. Numbers and structure of good practices in the particular years are shown in Table 2.

The data indicate social actions, including those for local communities, have been the most popular. Charity initiatives were the most numerous amongst the good practices reported. Actions for the development of entrepreneurship (start-up support, e.g. by means of business incubators) emerged as well.

Most environment good practices were carried out in 2013 (81 actions, i.e. $20.1 \%$ of all good practices). Regrettably, actions in this area declined in the next years by 8.2 and 7.5 percentage points $(\mathrm{pp})$, respectively. This implies that fewer and fewer enterprises were willing to spend on the environment in 2014-2015.

Actions in the area of the natural environment related to the stages of design (decisions to select raw materials), packing, distribution and waste disposal, regardless of where such processes are located. An enterprise should take into account its responsibility for impact on the environment at all stages of the production and supply chain and promote environment-friendly attitudes with stakeholders, including suppliers, consumers and all involved in a product life cycle. The society faces a range of environment challenges, including exhaustion of natural resources, pollution, climate change, destruction of natural habitats, extinction of species, annihilation of entire ecosystems and degradation of urban and rural areas where humans live. For these reasons, it is necessary to identify patterns of production and consumption and to ensure sustainable development of the whole economy. Enterprises introducing good environment practices in 20112015 (Figure 3) focused on ecological education. Most, namely, as many as $56.8 \%$ [2011], engaged in actions in this category. Their numbers sharply declined in the following years (a $34 \%$ fall in 2015), yet good practices in this field continued to prevail. Ecological education should be aligned with the strategy and business activities of an enterprise, bring benefits and contribute to the development of conscious and environment-sensitive consumers. An idea advanced by IKEA Łódź to offer a cycle of workshops for the youngest children called 'Little Things Change the World for the Better' was an interesting action along these lines. It involved educating customers to introduce principles of sustainable development to everyday life through a variety of ecological activities. As part of 'Little Gardener' workshops, children learnt basics of gardening, planting herbs and vegetables when supervised by animators. During 'Ecological Lamp' workshop, they learnt about the world and about how important water and greenery are to our planet. At the 'Home Herbarium' workshop, children found out working in the garden may be fun and pleasure and looking after plants is not difficult (RBF 2015). In 2011, 18.9\% enterprises conducted eco-office actions. The rate varied a little over the subsequent years, reaching its minimum in 2014 (a 12.5 pp drop compared to 2011).

Enterprises increasingly often take actions to cut adverse environmental impact in the workplace. They introduce ecological principles to their offices, appreciating the status of 'a green office'. Saving paper by printing on both sides of a sheet of paper or e-invoicing and e-accounting has become standard. In effect, not only the consumption of paper diminishes but also the flow of information between staff and stakeholders becomes more rapid. Green IT is another matter enterprises pay attention to. Both Bank Millennium and Polpharma have introduced systems of energy consumption monitoring and reduction, virtualised their server infrastructures, modernised computers, optimised printing, issue electronic statements and collect used toners and sell obsoleted phones and computers to their staff (RBF 2013).

The importance of environment-friendly programmes, launched by not only manufacturers but also service enterprises, rose significantly in 2014-2015. BPH Bank has for several years pursued an Environment Policy to build ecological awareness amongst staff, implement environment protection actions and promote such ideas with all stakeholder groups. EKO BPH programme consists of specific actions in several key areas: ecoculture, energy, water, paper, business trips and promotion of ecological attitudes (RBF 2015). 


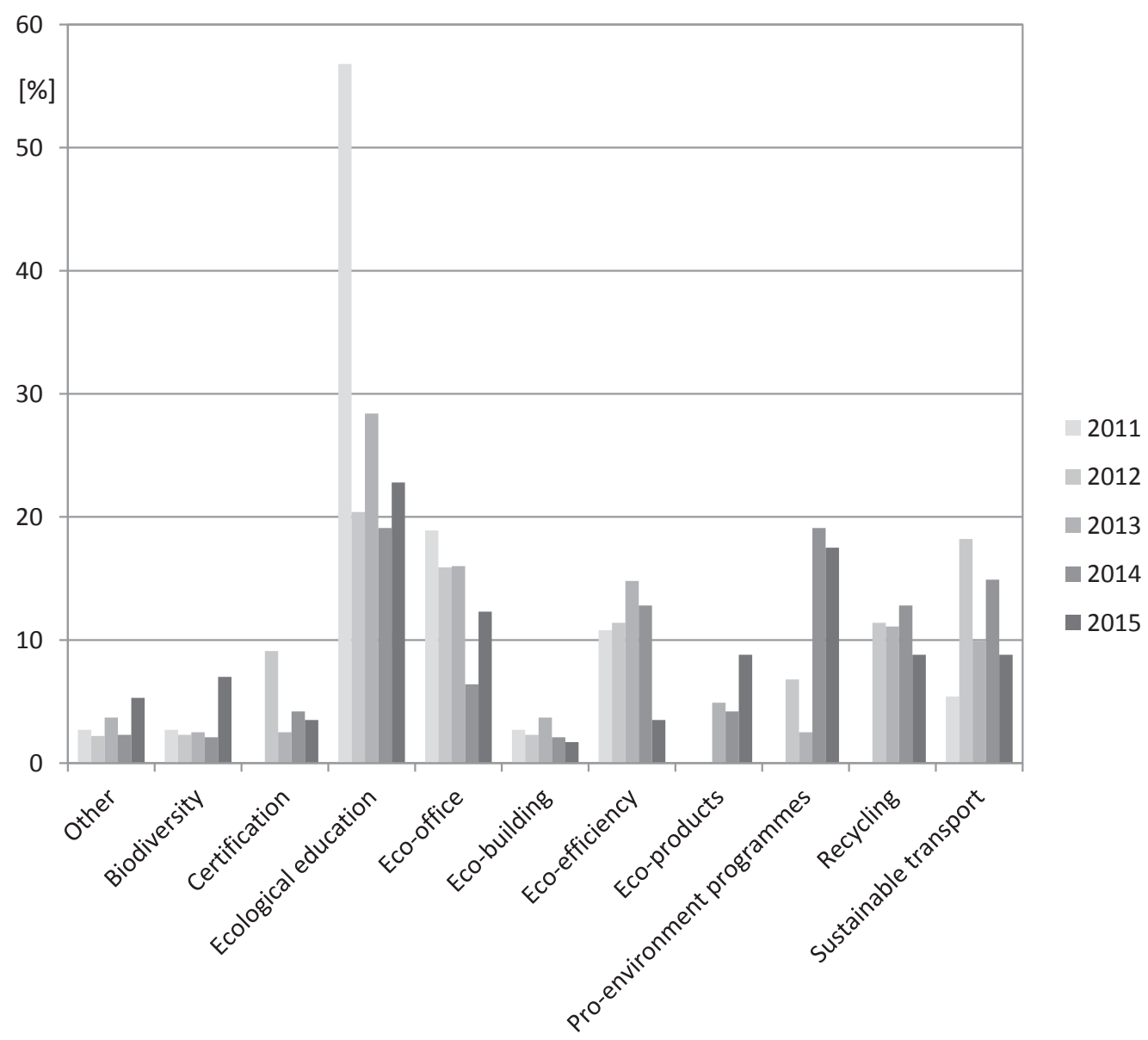

Figure 3. Structure of good practices in the area of environment. Source: The authors' own compilation based on the RBF data.

Good practices were not pursued in the areas of eco-products (2011-2012), certification (2011), pro-environment programmes and recycling (2011). Few enterprises (1.7-3.7\%) constructed green office buildings, reduced impact of their real properties on the environment or supported their sustainable development in the entire period studied.

\section{ACTIONS FOR ENVIRONMENT PROTECTION IN MAZOVIA - RESULTS OF THE AUTHORS' RESEARCH}

A study of enterprises seated in the Mazovian region, drawn at random from a database available at www.b2bbank.pl, was conducted in 2014-2016.

The research sample was selected in line with the first and second laws of randomisation, namely, each element of the general population had a chance to be drawn and elements of the same category were taken into account. Simple random selection was applied.

Interviews with the respondents were carried out as electronic mail survey. In June of 2014, 2015 and 2016, a survey questionnaire (research tool) was distributed to 400 enterprises. Phone calls were also made to invite participation, and the progress of the survey was monitored. The survey included a specification and 25 closed-ended questions on determinants of enterprise development, including 10 concerning issues related to CSR. One question asked for specifying the areas of CSR where an enterprise implements good practices. Rates of return of the surveys were $26.5 \%, 30.5 \%$ and $29.5 \%$ in the particular years, respectively.

The study involved private enterprises owned by self-employed individuals and domestic commercial companies. The enterprises were divided as set out in the Freedom of Business Act (1829 of 2016, Articles 104-106) and illustrated in Figure 4.

In 2016, 59.3\% of the enterprises queried applied the concept of CSR (0.3 pp more than that in 2015). On the other hand, approximately $40 \%$ of the enterprises conducted actions harmful to the environment, causing irreversible changes, in the whole period studied. The structure of enterprises surveyed that have implemented CSR ideas is shown in Table 3. Analysis of the data suggests dependence between frequency of CSR implementations and enterprise size. Most large enterprises (71.4\%) and fewest micro-entities (57.9\%) applied the principles of CSR in 2014. A similar dependence was obtained in the successive years. It can be observed that the larger an enterprise, the more often the CSR ideas are implemented.

The structure of good practices implemented by enterprises operating in Mazovia can be said to be very similar to the one 


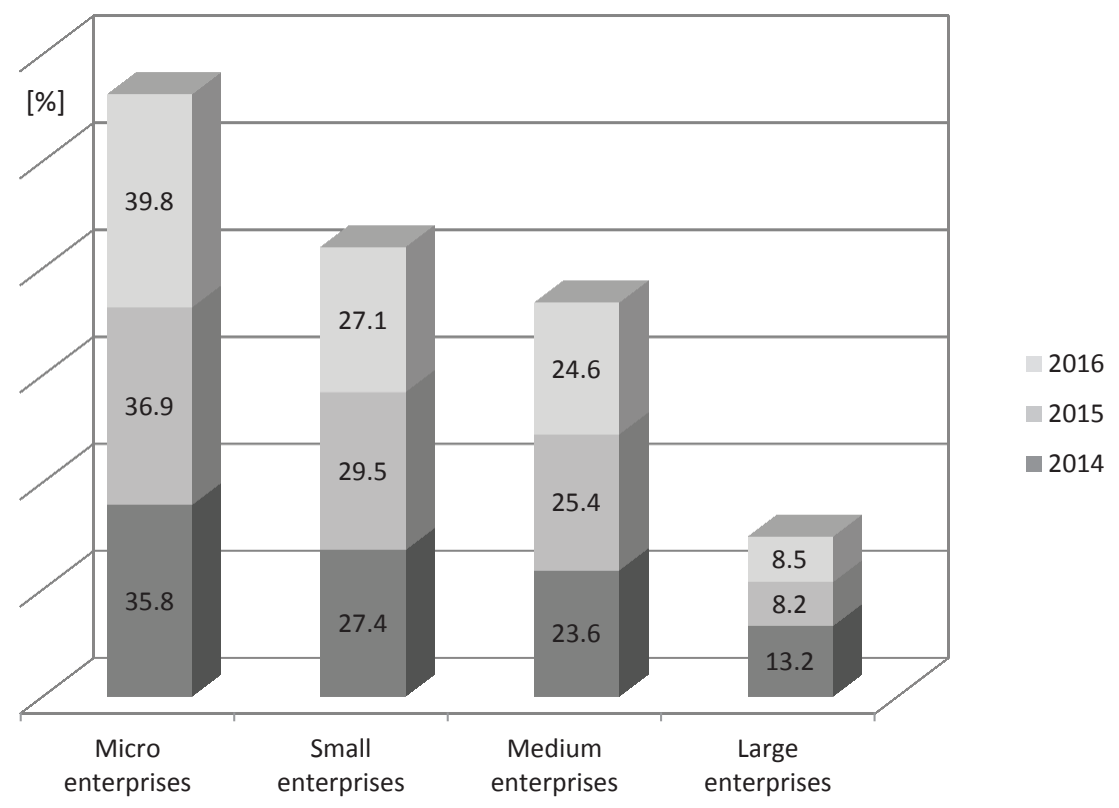

Figure 4. Division of enterprises surveyed by size.

Source: The authors' own compilation.

Table 3. Numbers of enterprises applying principles of Corporate Social Responsibility.

\begin{tabular}{|c|c|c|c|c|c|c|c|c|c|c|}
\hline \multirow{2}{*}{ Year } & \multicolumn{2}{|c|}{ Total, including: } & \multicolumn{2}{|c|}{ Micro-enterprises } & \multicolumn{2}{|c|}{ Small enterprises } & \multicolumn{2}{|c|}{$\begin{array}{l}\text { Medium-sized } \\
\text { enterprises }\end{array}$} & \multicolumn{2}{|c|}{ Large enterprises } \\
\hline & $\begin{array}{l}\text { without } \\
\text { CSR }\end{array}$ & with CSR & $\begin{array}{l}\text { without } \\
\text { CSR }\end{array}$ & with CSR & $\begin{array}{l}\text { without } \\
\text { CSR }\end{array}$ & with CSR & $\begin{array}{l}\text { without } \\
\text { CSR }\end{array}$ & with CSR & $\begin{array}{l}\text { without } \\
\text { CSR }\end{array}$ & with CSR \\
\hline 2014 & 40 & 66 & 16 & 22 & 12 & 17 & 8 & 17 & 4 & 10 \\
\hline 2015 & 50 & 72 & 18 & 27 & 18 & 18 & 12 & 19 & 2 & 8 \\
\hline 2016 & 48 & 70 & 21 & 26 & 16 & 16 & 10 & 19 & 1 & 9 \\
\hline
\end{tabular}

Source: The authors' own research.

indicated by the results of the national research (Figure 5). In 2014-2016, most enterprises implemented good practices in the areas of social commitment, development of local communities and labour practices. Their shares amounted to $77.3 \%, 64.5 \%$ and $57.3 \%$, respectively, in the particular years. The proportion of good practices in the area of natural environment was around $15 \%$ in the whole time under examination. Numbers of these actions tended to increase, though. Thirty-one actions in this area were conducted in the Mazovian region in the end of 2016, a $63 \%$ rise above 2014.

Actions of JARS are a good example of good practices in the area of environment in Mazovia. This is a medium-sized limited liability company that carries out laboratory research and consultation services in the field of environment protection. To mobilise its staff to do voluntary work, the enterprise has offered to monitor cleanliness of Zegrze Reservoir waters. Their action is also designed to preserve local natural environment and to boost awareness of environmental protection amongst local community. Research into the natural environment by means of the state-ofthe-art tools causes the company staff to naturally acquire unique and interesting knowledge of natural processes. They pass their experience on to students of local schools.

Added to all that, JARS works with the Warsaw University of Life Sciences and the University of Silesia to run student training and graduate internships, help with diploma research and provide financial and material support for educational and scientific activities (www.jars.pl).

Good environment practices are also conducted by Rekopol Organizacja Odzysku Opakowań, a joint-stock company. This enterprise assists others with fulfilling legal requirements with regard to recycling and recovery of waste packaging. This consists in both assuming this obligation and the additional actions for including advice on its fulfilment in other countries and waste consultation.

Ecological education is another tool influencing effectiveness of the company's activities. Rekopol runs public educational campaigns to raise motivation, spread knowledge and encourage improved and more conscious waste segregation to expand flows of good quality materials to be recycled [www.rekopol.pl]. 
social commitment and development of local communities

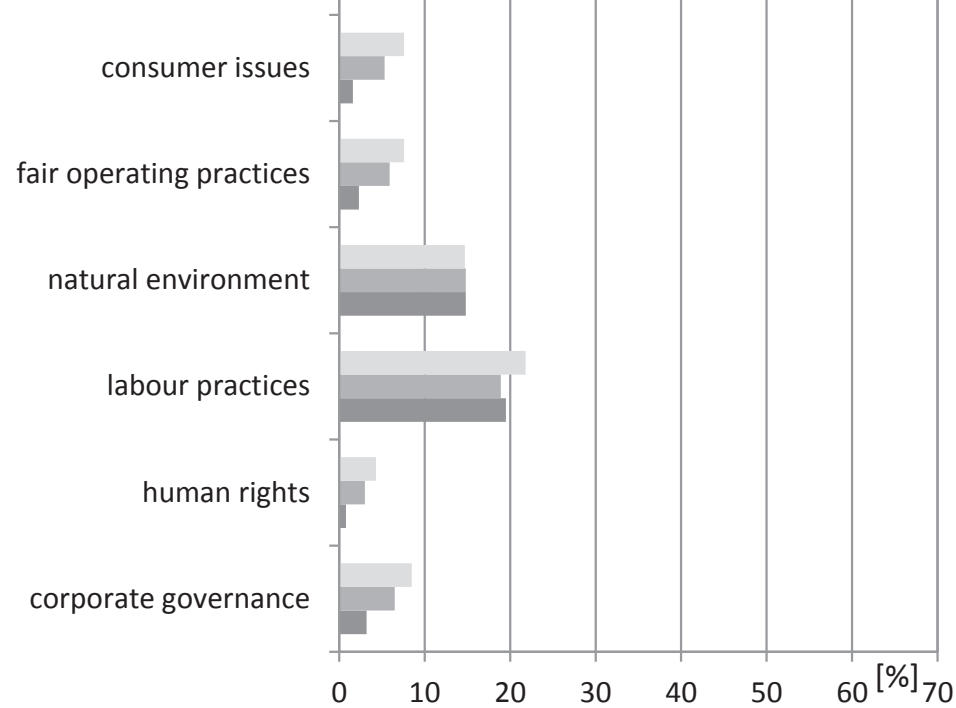

Figure 5. Structure of good practices in Mazovia.

Source: The authors' own research.

\section{CONCLUSION}

A socially responsible enterprise strives for satisfactory financial performance whilst following principles of sustainable development and should, therefore, address economic, social, legal, moral, ecological and charity aspects in its projects.

Organisations implementing the concept of CSR rely on the principles of professional ethics and fair competition whilst supporting social and cultural events. What is more, they manage human resources appropriately, caring first of all for their safety, motivation and development. Protection of the natural environment is a major area of enterprises' social responsibility. In light of national empirical research and the authors' survey of enterprises in the Mazovian region, the hypotheses of this article can be said to be true. The results demonstrate that

- Numbers of good practices implemented by socially responsible enterprises increase. In 2011, 209 new CSR actions were noted. Their growth was the most dramatic in 2013 (a rise by ca. 65\% above the preceding year) and

\section{REFERENCES}

AMALRIC F., HAUSER J. 2005. Economic drivers of corporate social responsibility activities, Journal of Corporate Citizenship. 20,4:27-38.

BASU K., PALAZZO G. 2008. Corporate Social Responsibility: a Process Model of Sensemaking, Academy of Management Review. 33, 1: 122-136.

BOWEN H. R. 1953. Social responsibility of the businessman, Harper \& Row, New York.

COMMUNICATION FROM THE COMMISSION TO THE EUROPEAN PARLIAMENT, THE COUNCIL, THE EUROPEAN ECONOMIC AND SOCIAL COMMITTEE they reached an approximately $117 \%$ growth above 2011 at the end of the research period. The rate of growth of good practices was far slower in Mazovia. There were 211 good practices in 2016, about 60\% more than those in 2014.

- Enterprises most commonly engage in actions in the areas of social commitment, development of local communities and labour practices. Their overall proportion accounted for $58.8-66.1 \%$ in the national research. The share of the natural environment good practices reached a maximum of $20.1 \%$ in 2013. Similar relations were obtained in Mazovia. Good practices in the areas of social commitment, development of local communities and labour practices prevailed in this region as well, whereas actions in the area of the natural environment constituted around $15 \%$ of all the practices.

The concept of CSR enforces certain undertakings and behaviours. It is important for organisations to go beyond set patterns of action and take initiative to support and realise projects fostering the environment.

AND THE COMMITTEE OF THE REGIONS, A renewed EU strategy 2011-14 for Corporate Social Responsibility. Brussels, 25.10.2011, COM(2011) 681 final.

CRAIG SMITH N. 2003. Corporate social responsibility: not whether, but how? Centre for Marketing Working Paper, London Business School. 03-701: 1-37.

$\mathrm{CROUCH}$ C. 2006. Modelling the Firm in its Market and Organizational Environment: Methodologies for Studying Corporate Social Responsibility. Organization Studies. 27, 10: 1533-1551. 
FORUM ODPOWIEDZIALNEGO BIZNESU (RBF) 2011-2015. Odpowiedzialny Biznes w Polsce. Dobre Praktyki. Forum Odpowiedzialnego Biznesu, Warszawa.

FREDERICK W.C. 1986. Toward CSR-3: Why Ethical Analysis is Indispensable and Unavoidable in Corporate Affairs California Management Review. 28, 2:126-141.

FRIEDMAN M. 1970. The social responsibility of business is to increase its profits. The New York Times Magazine, September 13.

GASIŃSKI T., PISKALSKI G. 2009. Zrównoważony biznes podręcznik dla małych i średnich przedsiębiorstw. Ministerstwo Gospodarki. Warszawa.

GOŁASZEWSKA-KACZAN U. 2009. Zaangażowanie społeczne przedsiębiorstwa. Wydawnictwo Uniwersytetu w Białymstoku, Białystok.

GRIFFIN R.W. 2005. Podstawy zarządzania organizacjami, Wydawnictwo Naukowe PWN, Warszawa.

HĄBEK P. SZEWCZYK P. 2010. Społeczna odpowiedzialność a zarządzanie jakością, Wydawnictwo Politechniki Śląskiej, Gliwice.

HYS K., HAWRYSZ L. 2013. CSR in Poland as a important foundations of modern societies, Management Study. 1, 1:2733.

INTERNATIONAL ORGANIZATION FOR STANDARDIZATION, ISO 26000:2010.

KAZOJĆ K. 2014. Koncepcja Społecznej Odpowiedzialności i jej obszary w organizacjach. Zeszyty Naukowe Uniwersytetu Szczecińskiego. Studia i Prace Wydziału Nauk Ekonomicznych i Zarządzania. 38, 1: 57-70.

KOTLER P., LEE N. 2005. Corporate social responsibility: Doing the most for your company and your cause. Hoboken, NJ: John Wiley and Sons, Inc.

LAMBERTINI L., PALESTINI A., TAMPIERI A. 2016. CSR in an Asymmetric Duopoly with Environmental Externality, Southern Economic Journal. 83,1: 236-252.

MARÁKOVÁ V., LAMENT M., WOLAK-TUZIMEK A. 2015. Reporting standards in socially responsible enterprises, Economic Annals-XXI. 9-10, 1:56-59.

MCWILLIAMS A., SIEGEL D. 2001. Corporate Social Responsibility: A Theory of the Firm Perspective. Academy of Management Review. 26,1: 117-127.

MCWILLIAMS A., SIEGEL D.S., WRIGHT P.M. 2006. Corporate social responsibility: Strategic implications. Journal of Management Studies. 43, 1:1-18.
POGONOWSKA B., WOJTASIEWICZ L. 2008. Podstawowe informacje o idei społecznej odpowiedzialności biznesu (CSR), [w:] Wojtasiewicz L. (red.), Społeczna Odpowiedzialność Biznesu. Raport z badania działalności firm należących do Klubu Partnera Akademii Ekonomicznej w Poznaniu, AE Poznań, Centrum Badania Gospodarki Regionalnej, Poznań:7-12.

PORTER M.P., KRAMER M.R. 2006. Strategy and Society: The Link between Competitive Advantage and Corporate Social Responsibility. Harvard Business Review. 84, 12,4: 78-92.

RATAJCZAK M., SAWICKA E. 2008. Społeczna odpowiedzialność biznesu (CSR) jako narzędzie podnoszenia konkurencyjności sektora MSP, [w] Bąk M., Kulawczuk P. (red.), Społeczna odpowiedzialność biznesu w małych i średnich przedsiębiorstwach. Instytut Badań nad Demokracją i Przedsiębiorstwem Prywatnym, Warszawa: 131-143.

ROK B. 2012. Społeczna odpowiedzialność biznesu, [w:] Gasparski W. (red.), Biznes, etyka, odpowiedzialność, Wydawnictwa Profesjonalne PWN, Warszawa: 423-432.

SALA P. 2015. Zakres odpowiedzialności przedsiębiorstwa na przykładzie normy ISO 26000, Zeszyty Naukowe Politechniki Śląskiej, Seria: Organizacja i Zarządzanie. 82: 173-186.

SEN S., BHATTACHARYA C.B. 2001. Does doing good always lead to doing better? Consumer reactions to corporate social responsibility, Journal of Marketing Research. 38, 2: 225-243.

STAWICKA E., WOŁOSZYN J. 2013. Praktyczne podejście przedsiębiorstw sektora MŚP do koncepcji społecznej odpowiedzialności w biznesie, Roczniki Ekonomii Rolnictwa i Rozwoju Obszarów Wiejskich. 100, 1: 44-51.

Ustawa z 02 lipca 2004 r o swobodzie działalności gospodarczej tj. Dz. U z 2016 r. poz. 1829.

VAN MARREWIJK M. 2003. Concepts and definitions of CSR and corporate sustainability: Between agency and communion. Journal of Business Ethics. 44, 2/3: 95-105.

VISSER W. 2007. Revisiting Carroll's CSR Pyramid, [in:] Crane A., Matten D., Spence L.J. (eds), Corporate Social Responsibility: Readings and Cases in a Global Context, Routledge, London: 29-56.

WOŁOWIEC T. 2004. Społeczna odpowiedzialność przedsiębiorstwa nową formułą zarządzania. Ekonomika i Organizacja Przedsiębiorstw. 3: 3-11. 